\title{
Cold comfort for the catarrhal child
}

John Fry coined the phrase 'the catarrhal child' to describe the child we all know only too well with ever running nose whose desperate mother begs us to do something to staunch the flow of mucus. An understanding of the epidemiology and pathogenesis of upper respiratory tract viral infections may not enable us to stop the nose from running, but it can help us not to prescribe valueless medications and not to investigate the children unnecessarily.

\section{Respiratory viruses}

Children experience more respiratory virus infections than adults because their secretory immune system is relatively immature, because they have not encountered the viruses before, and because they are exposed to more such viruses than most adults. There are over 100 strains of rhinovirus, and infection with one strain provides little or no cross protection against infection with a different strain. Coronaviruses are another important cause of upper and lower respiratory tract infections in preschool children. ${ }^{1}$ Other viruses that can cause childhood respiratory infections include parainfluenza viruses, influenza viruses, adenoviruses, and enteroviruses. Respiratory syncytial virus not only causes bronchiolitis in infancy, but older children can be reinfected every winter, with successively milder infections, which can nevertheless result in otitis media or a febrile cold with coryza, cough, and sore throat. ${ }^{2}$

\section{Epidemiology}

Recurrent respiratory tract infections are normal in the first few years of life. Maternal antibody gives relative protection for the first three to six months and breast feeding also protects against respiratory viruses but, as passively acquired antibody wanes, the child becomes more susceptible to respiratory infections. These comprise about $85 \%$ of childhood infections. ${ }^{3}$

The number of infections experienced by each child depends on several factors of which the most important is probably the intensity of exposure to respiratory viruses. In an important longitudinal study of childhood infections in Cleveland, Ohio, Dingle et al found that children under 5 years old who attended nursery school had on average 12 respiratory infections per year. ${ }^{4}$ Children of the same age not attending school but with a sibling at school had a mean of nine infections per year, while children of the same age not at school and with no sibling at school had six to seven infections annually. Day care attendance results in an increased incidence of respiratory infections. ${ }^{56}$ If children attend day care in the first year of life, then this becomes the year in which they experience most respiratory infections. ${ }^{6}$ The average preschool child will have six to eight respiratory tract infections a year in their preschool years, with the maximum incidence from 2 to 4 years of age. ${ }^{34}$

Urban children experience more respiratory infections than rural children, probably due to increased exposure. Maternal smoking is an important factor in determining the incidence of childhood respiratory infections, ${ }^{5}$ and if parents cannot be persuaded to stop smoking they should at least be prevailed upon to smoke outdoors.

Infections tend to be more frequent in the winter months, although parainfluenza virus infections occur mainly in the summer and enterovirus infections in the late summer and early autumn, so that a child can have infections most of the year. In a longitudinal cohort study of children with recurrent respiratory tract infections, many of whom conformed admirably to John Fry's description of the catarrhal child, we found that children would develop rhinitis due to a proved respiratory viral infection with a clear nasal discharge which rapidly became mucopurulent. The nasal discharge would last 10 to $\mathbf{1 4}$ days, dry up for a day or two, then the child would be infected by a different virus and the process would recommence. ${ }^{7}$ Thus a superficial appearance of continuous rhinitis was in fact due to recurrent viral infections. Mucopurulent nasal discharge does not imply bacterial superinfection, as it is commonly seen in colds with little or no change in bacterial flora, ${ }^{78}$ and antibiotics are not indicated unless the child has an additional indication such as otitis media.

\section{Pathophysiology}

The nasal secretions in rhinorrhoea contain a number of proteins. Mucous glycoproteins are secreted by goblet cells and by serous and mucous glandular cells in the submucosal glands. Albumin is synthesised in the liver, circulates as a vascular protein, and diffuses into glandular secretions passively when vascular permeability increases. ${ }^{9} 10$ Monomeric IgA is synthesised by plasma cells restricted to the periglandular region. ${ }^{10}$ Secretory component is made by serous cells in the seromucous glands. Secretory IgA, two molecules of IgA linked together by a joining $(\mathrm{J})$ chain and secretory component, is solely a glandular product. ${ }^{1011}$ Interferon beta is produced by nasal fibroblasts in response to viral infection while local interferon alfa is produced by lymphocytes and probably by a number of other types of nucleated cell. ${ }^{12} 13$

Rhinoviruses cause little damage to the nasal epithelium during colds ${ }^{14} 15$ so it is probable that coryzal symptoms are largely due to inflammatory mediators. Nasal provocation tests performed on normal and atopic adults using histamine and the cholinergic drug methacholine suggest that secretory IgA secretion may be under cholinergic control, ${ }^{10}$ whereas histamine increases plasma protein extravasation, stimulates glandular secretion, ${ }^{16}$ and increases the proportion of IgG in nasal secretions. ${ }^{17}$ Nasal provocation tests only examine the response to a single exogenous substance, a very unphysiological situation, and their relevance to what occurs in an infection is doubtful.

Naclerio and colleagues measured concentrations of inflammatory mediators in nasal secretions of young adults during experimental rhinovirus colds. ${ }^{18}$ They found that nasal concentrations of histamine did not increase during colds, whereas volunteers who became symptomatic had a considerable rise in nasal concentrations of bradykinin and related kinins. They postulated that kinins, particularly bradykinin, might be responsible for the symptoms of rhinovirus colds. Trials of antihistamines have shown little or no benefit in alleviating the symptoms of colds, ${ }^{19} 20$ and Naclerio et al suggested the development and study of kinin antagonists.

Another possible candidate for causing some of the symptoms of colds is interferon. When interferon alfa is injected into volunteers it causes flu like symptoms such as fever, malaise, headache, and myalgia. ${ }^{21}$ During viraemic infections interferon alfa can be detected in the serum ${ }^{22}$ and interferon may be responsible for some of the systemic effects of viraemic respiratory infections such as influenza. 
Local administration of interferon by nasal spray often causes nasal stuffiness, congestion, mild epistaxis, and sore throat within a few days. ${ }^{23}$ Interferon is probably not the sole cause of the nasal symptoms of colds, however, as respiratory syncytial virus causes rhinorrhoea and sore throat in adult volunteers who do not mount a significant nasal or systemic interferon response to infection with this virus. $^{24}$

\section{Investigation of recurrent respiratory infections}

Parental anxiety is a common reason for children presenting to general practitioners and paediatricians with 'too many' respiratory infections. If the doctor is satisfied, after taking a history, that the child is experiencing no more than his or her expected quota of viral respiratory infections, reassurrance of the parents will usually quell the anxiety. Persistent anxiety indicates that either the child or the parents has a real problem.

Localisation of signs and symptoms to a single site is suggestive of an anatomical cause. For example unilateral mucopurulent nasal discharge may be due to a foreign body or a unilateral choanal atresia. Recurrent lower respiratory tract infections may be due to a number of different causes outside the scope of this annotation, and require further investigation.

Allergic rhinitis may cause seasonal or perennial rhinitis, ${ }^{25}$ and this is an important differential diagnosis for the child with suspected recurrent upper respiratory tract infections. There may be a history of nasal symptoms in association with exposure to potential allergens such as feathers, house dust, grass, or other pollens. This is not always present but can give a useful lead. In allergic rhinitis the child often has other atopic diseases, with asthma particularly common, ${ }^{25}$ or there is a family history of atopy. Nasal stuffiness, sneezing, and itching of the nose are often more troublesome than rhinitis. Nasal smears should be examined for mast cells as their presence is a more specific and more sensitive test of allergic rhinitis than the presence of eosinophils. ${ }^{25}$

Children with recurrent upper respiratory tract infections should probably be investigated for immune deficiency only if there are features of their infections or additional factors to suggest such a problem. Recurrent acute otitis media may be due to recurrent viral or bacterial infections which, unless tympanotomy is performed as is routine in some parts of Europe, cannot be distinguished easily. Chronic or recurrent purulent ear discharge is suggestive of recurrent bacterial infections and of immune deficiency. Hypogammaglobulinaemia may present in this way, as may IgG subclass deficiency, particularly $\operatorname{IgG}_{2}$ deficiency. As total serum IgG concentrations are often in the normal range in children with $\operatorname{IgG}_{2}$ subclass deficiency, it is wise to measure total serum immunoglobulin and IgG subclass concentrations in children with recurrent otitis media, particularly when there is purulent otorrhoea.

A family history of recurrent or severe infections may be an important clue to immune deficiency. Persistent candidiasis, particularly if there is nail as well as oral involvement (mucocutaneous candidiasis), is suggestive of defective $T$ lymphocyte function. Infections with opportunist organisms such as Pneumocystis carinii or nocardia almost certainly indicate a profound $\mathrm{T}$ cell defect, as do severe infections with certain common viruses such as giant cell pneumonia from measles or haemorrhagic chickenpox.

\section{Treatment}

Osler stated 'there is just one way to treat a cold and that is with contempt'. No medicine has yet proved to be significantly more effective, and a number of remedies for colds and catarrh are potentially harmful. Unnecessary antibiotics should be avoided, as should antihistamines, decongestants, and cough suppressants. Most children with recurrent infections eventually grow out of them, a truism of some modest comfort to the beleaguered parents.

DAVID ISAACS

Department of Immunology and Infectious Disease,

Children's Hospital,

Camperdown,

$N S W 2050$,

Australia

Isaacs D, Flowers D, Clarke JR, Valman HB, McNaughton MR. Epidemiology of coronavirus respiratory infections. Arch Dis Child 1983;58:500-3.

Parrott RH, Kim HW, Arrobio JO, et al. Epidemiology of respiratory synctia virus infection in W/ashington D.C. II. Infection and disease with respect to virus infection in Washington D.C. II. Infection and disease with respect

3 Roberton DM, Hosking CS. Childhood infections-how often and how many? Modern Medicine of Australia 1985;5:20-3.

4 Dingle JH, Badger GF, Jordan WS. Illness in the home. Cleveland, Ohio: Press of Western Reserve University, 1964.

5 Fleming DW, Cochi SL, Hightower AW, Broome CV. Childhood upper respiratory tract infections: to what degree is incidence affected by day-care respiratory tract infections: to what deg

6 Loda FA, Glezen WP, Clyde WA. Respiratory diseases in group day care. Pediatrics 1979;49:428-37.

7 Isaacs D, Clarke JR, Tyrrell DAJ, Valman HB. Selective involvement of the lower respiratory tract by respiratory viruses in children with recurrent respiratory tract infections. $\mathrm{Br} M e d \mathrm{f}$ 1982;284:1746-8.

8 Todd JK, Todd N, Damato J, Todd WA. Bacteriology and treatment of purulent nasopharyngitis: a double-blind, placebo-controlled evaluation. Pediatr Infect Dis 1984;3:226-9.

9 Widdicombe JG, Wells UM. Airway secretions. In: Proctor G, Anderson A, eds. The nose: upper airway physiology and the atmospheric environment. Amsterdam: Elsevier Biomedical Press, 1982:215-44.

10 Raphael G, Druce H, Baraniuk J, Kaliner M. The pathophysiology of rhinitis. I. Assessment of the sources of protein in methacholine-induced nasa secretions. Am Rev Respir Dis 1988:138:413-20.

11 Raphael G, Hauptschein-Raphael M, Kaliner M. Gustatory rhinitis: a syndrome of food-induced rhinorrhoea. F Allergy Clin Immunol 1989;83:110-5.

$2 \mathrm{Hall}$ CB, Douglas RG Jr, Simons RL, Geiman JM. Interferon production in children with respiratory syncytial, influenza and parainfluenza virus infec-
chent children with respiratory syncytia
tions. $₹$ Pediatr $1978 ; 93: 28-32$.

$13 \mathrm{McIntosh} \mathrm{K}$. Interferon in nasal secretions from infants with viral respiratory tract infections. $\mathcal{F}$ Pediatr 1978;93:33-6.

14 Raphael GD, Meredith SD, Baraniuk JN, Druce HM, Banks SM, Kaliner MA. The pathophysiology of rhinitis. II. Assessment of the sources of protein in histamine-induced nasal secretions. Am Rev Respir Dis 1989;139: 791-800.

15 Winther B, Farr B, Turner RB, et al. Histopathologic examination and enumeration of polymorphonuclear leukocytes in the nasal mucosa during experimental rhinovirus colds. Acta Otolaryngol 1984;413(suppl):19-24.

16 Turner RB, Hendley JO, Gwaltney JM. Shedding of infected ciliated cells in rhinovirus colds. F Infect Dis 1982;145:849-53.

17 Meredith SD, Raphael GD, Baraniuk JN, Banks SM, Kaliner MA. The pathophysiology of rhinitis. III. The control of IgG secretion. $\mathcal{F}$ Allergy Clin Immunol 1989;84:920-30.

18 Naclerio RM, Proud D, Kagey-Sobotka A, Lichtenstein LM, Hendley JO, Gwaltney JM. Is histamine responsible for the symptoms of rhinovirus colds? A look at the inflammatory mediators following infection. Pediatr colds? A look at the inflammat
Infect Dis $\mathcal{F} 1988 ; 7: 218-22$.

19 Gaffey MJ, Kaiser DL, Hayden FG. Ineffectiveness of oral terfenadine in natural colds: evidence against histamine as a mediator of common cold natural colds: evidence against histamine as a

20 symptoms. Pediatr Infect Dis A double-blind, placebo-controlled clinical trial of the effect of chlorphenirA double-blind, placebo-controlled clinical trial of the effect of chlorpheniramine on the response of the nasal airway, middle ear and eustachian tube

21 scott GM, Secher DS, Flowers D, Bate J, Cantell K, Tyrrell DAJ. Toxicity of cott GM, Secher DS, Flowers D, Bate J, Canter
interferon. Br Med $\mathcal{f} 1981 ; 282: 1345-8$.

22 interferon. $\mathrm{Br}$ Med $\mathrm{f}$ 1981;282:1345-8.

23 Scott GM, Philpotts RJ, Wallace J, Secher DS, Cantell K, Tyrrell DAJ. Purified interferon as protection against rhinovirus infection. $\mathrm{Br} \mathrm{Med} \mathcal{J} 1982$; 284:1822-5.

24 Hall CB, Douglas RG Jr, Simon RL. Interferon production in adults with respiratory syncytial virus infection. Ann Intern Med 1981;94:53-5.

25 Kemp A, Bryan L. Perennial rhinitis. A common childhood complaint. Med $\mathcal{F}$ Aust 1984;141:640-3. 